\title{
Perceptions and Behaviors Regarding Seafood Consumption Following the Deepwater Horizon Oil Spill
}

\author{
By Mildred Naquin* \\ Wynn Gillan ${ }^{\dagger}$ \\ Ephraim Massawe \\ Caitlyn Haynes ${ }^{+}$ \\ Jessica Osborn ${ }^{\circ}$ \\ Marie Zannis
}

The Deepwater Horizon oil explosion in the Gulf of Mexico (United States of America) had an impact on those living in Louisiana, including job and income loss, and changes in seafood consumption. This study examined perceptions and behaviors related to seafood consumption for students/staff at a Louisiana university. After university approval, 1,436 randomly selected individuals were sent an explanatory email with a link to survey questions. Non-responders received second and third requests at three-week intervals, resulting in 239 participants. Concern about the safety of seafood was greatest six months after the spill. Nearly two-thirds indicated no change while 35\% decreased seafood consumption. Before the spill, $43 \%$ asked about the seafood source, while $64 \%$ did after. Respondents changed consumption patterns during and after the spill. Most expressed concern regarding the oil and use of dispersants. Behaviors were influenced primarily by $T V$ and newspapers which respondents considered trustworthy.

Keywords: Consumer attitudes, Environmental health, Oil spills.

\section{Introduction}

The Gulf of Mexico (Gulf) coastal region of the United States (US) affords tremendous benefits to the people of all states bordering the Gulf as well as numerous parts of the country. The Gulf coast region provides sources of food, recreational areas and other economic resources (National Marines Fisheries Services - NMFS 2007). Throughout each year, recreational and commercial fishermen catch large quantities of fish and shellfish. The Gulf of Mexico also presents recreational areas with scenic views and widespread appeal. Oil and natural gas resources of this area support the large Gulf energy sector.

The Gulf of Mexico's 600,000 cubic miles of water presents an environment that supports more than 21 million people and over $50 \%$ of all the US recreational fishing activities (NMFS 2007, Gulf of Mexico Alliance GMA 2008, National Oceanic and Atmospheric Administration - NOAA

\footnotetext{
* Professor, Southeastern Louisiana University, USA.

'Southeastern Louisiana University, USA.

* Southeastern Louisiana University, USA.

${ }^{+}$Southeastern Louisiana University, USA.

${ }^{\circ}$ Southeastern Louisiana University, USA.

- Health Education Consultant, Nicholls State University, USA.
} 
2015). In the US, the Gulf produces over $90 \%$ of the oil and natural gas, and provides over half of the ocean-dependent jobs and more than 800,000 jobs related to tourism and recreation (NOAA 2015). All the states bordering the Gulf of Mexico have a combined Gross Domestic Product (GDP) of more than two trillion dollars, part generated by the petroleum and natural gas industry (GMA 2008). According to Quest Offshore, the Gulf of Mexico's Oil and Natural Gas Industry contributes upwards of 45 billion dollars to the country's GDP (Quest Offshore 2011).

While the Gulf of Mexico can offer great benefits, any contamination from various oil and natural gas sources can greatly impact this ecosystem as a food reservoir. As a result, the implications for risks and adverse health effects to consumers may be profound. Research prior to the Deepwater Horizon (DWH) Gulf oil spill indicates that consumer perceptions about seafood, particularly wild or farmed fish, were favorable (Verbeke et al. 2005). Individuals' perceptions about seafood safety could be affected by numerous factors, such as perceived severity and susceptibility as noted in the Health Belief Model (Becker et al. 1974). These factors could significantly impact consumption patterns. Seafood consumption patterns especially among women may change as a result of perceived or real human health risks (Trondsen et al. 2003).

On April 20, 2010, residents of the Gulf of Mexico coastline experienced an industrial disaster that changed their lives and the ecosystems they depended upon for their livelihoods for years. Horowiltz's (2014) interviews with the residents of Louisiana revealed that they had never seen anything like this before, which was echoed by the US President's assessment as the worst disaster America has ever faced. The explosion resulted from the blowout of the British Petroleum (BP) drilling vessel, Deepwater Horizon, operated by Transocean at the Mississippi Macondo Prospect \#1. It occurred at about 5,000 feet deep in the Gulf of Mexico and 100 miles off the coast of Louisiana (Deepwater Horizon Study Group - DHSG 2011).

As it became clear that the BP oil spill was a national disaster, television (TV) stations, newspapers and other media outlets covered it for months; and public discussions at academic institutions, industry and local communities were also held during the immediate aftermath of the explosion. A significant number of residents in the region, particularly those in Louisiana, were kept abreast of the events and were made aware of efforts to control the spill (Hoffbauer and Ramos 2014). However, other issues concerning human health risks, whether real or perceived, and the communication of such risks as dispersants may not have been adequately covered by the media (Walker et al. 2015). For example, polycyclic aromatic hydrocarbons (PAH) and dispersants were found in many seafood specimens collected from the Gulf of Mexico one year after the spill (Ylitalo et al. 2012). In a period of 84 days, from the time of the oil spill to when the leakage was capped in July, 2010, the news coverage ranged from discussions on the economic issues to health and environmental impacts of this disaster (Greiner et al. 2013).

It is estimated about 4.4 million barrels (170 million gallons or $7.0 \times 10^{5}$ $\mathrm{m}^{3}$ ) were released into the Gulf during the entire three month period of the oil 
spill, approximately 20,000 to 40,000 barrels of oil a day (Crone and Tolstoy 2010, Spotts 2010, Robertson and Krauss 2010). The BP oil spill event was reported to be the largest offshore oil spill of our time in the entire oil industry (National Commission on the BP Deepwater Horizon Oil Spill and Offshore Drilling 2011). Within ten days of the BP oil spill, there were reports that the oil slick covered an area of more than 3,800 square miles along the shore line of the Gulf coast of Texas, Louisiana, Mississippi, Alabama and Florida (Columbia Broadcasting System - CBS News 2010). This impacted more than 14 million people. Economic, social and environmental impacts were estimated at 40 billion dollars to BP itself and the entire region (Devi 2010, Smith et al. 2011, Plater 2010, McCauley 2010). News of the amount of the oil released into the environment possibly raised public awareness causing concern about the risks of local seafood consumption.

Other issues of great concern to the community and the environment were the over two (2) million gallons of dispersants used to clean up the oil (Shaw 2010). In the aftermath of the spill, the US Environmental Protection Agency (EPA) granted BP the permission to use approximately 1.07 million gallons and 771,000 million gallons of dispersants at the surface and subsea, respectively (Kilduff and Lopez 2011). One of the dispersants which contained 2-Butoxyethanol, according to the Material Safety Data Sheets (MSDS), may cause acute illnesses and damage to red blood cells, kidneys, and the liver (MSDS 2005). Depending on the composition and the environment in which dispersants are used, either in an aerobic or anaerobic condition, their efficiency may range from $50 \%$ to $60 \%$, rarely reaching $80 \%$ (Berna et al. 2007). With such efficiencies, there were varying amounts of oil and dispersants on the surface and under the sea (Camilli et al. 2010, Wang and Roberts 2010). With more than 5 million liters of dispersants released, the largest amount used in history, Biello questioned whether this approach was in fact intended to remove or introduce pollution in the Gulf (2010). Evidently, all these issues, individually or combined, may potentially affect individuals' perception of seafood and limit their consumption in the short and/or long term.

\section{Purpose}

This article explains how the Deepwater Horizon British Petroleum oil spill of April 2010 may have affected health risk perceptions and resulting seafood consumption patterns of residents in the heavily impacted areas of southeastern Louisiana, US. Specifically this study explored risk perceptions and associated behaviors of students, faculty and staff at a Louisiana university one year after the 2010 Deepwater Horizon oil spill. Our research question therefore was to determine if the DWH oil spill influenced seafood consumption patterns among a sample of Louisiana residents. Secondary questions included: 
- What were the levels of concern about the safety of the seafood before, during and after the spill, and did this vary by demographics?

- What were the levels of concern in regard to the oil and the use of dispersants?

- Was seafood consumption impacted by the DWH oil spill and what demographics were more likely to be affected?

- What were the primary sources of information that impacted seafood consumption and did this vary by demographics?

\section{Methods}

\section{Subjects}

All study procedures were approved by the university Institutional Review Board. The university's Office of Institutional Research produced a stratified random sample of 1,426 potential participants. This included faculty, staff, undergraduate and graduate students. A mass email with a link to complete a SurveyMonkey ${ }^{\circledR}$ questionnaire was sent encouraging participation with passive informed consent. After two weeks, a second online questionnaire prompt was emailed to those who did not respond to the initial request. After an additional two weeks, a third request was sent again to potential participants. Out of 1,200 emails, 239 responded for an overall response rate of $20 \%$. Respondents completing the survey were comprised of $65 \%$ students and $35 \%$ faculty/staff.

\section{Survey Instrument}

A questionnaire was developed to assess factors influencing perception of seafood safety and health risks. Survey items measured seafood consumption patterns, fiduciary impacts (job and income loss), concern about Gulf seafood safety and health risks, along with participant's physical distance from the Gulf of Mexico. Professionals from the university and the National Oceanic and Atmospheric Administration (NOAA - USA) determined questionnaire content and face validity. These professionals had extensive experience in survey development and administration.

In addition, a pilot study was conducted with selected students and faculty members at the university. Comments from NOAA professionals and the pilot study participants were used to improve the readability of the survey. In addition more changes were made to include culturally sensitive wording, especially in demographic questions.

Participants received an explanatory email with a link to demographic, behavioral and perception items. Standard demographic questions were asked along with questions about the distance respondents lived from the Gulf of Mexico. One behavioral question asked: "After the Gulf oil spill, how often did you usually eat the following seafood from the Gulf of Mexico?". Seafood included fish, oysters, shrimp, crabs and other seafood. Response choices were: 
never, once per month or less, 2-3 times a month, once a week, twice a week, and three or more times a week. Perceptions of risk were determined by responses to questions such as, "Rank your concerns from 1 (not concerned) to 5 (extremely concerned) about the safety of eating Gulf seafood". The five time frames for this item included: before the spill, April-May 2010, June-July 2010, August-September, 2010 and currently.

\section{Outcome Measures}

Dependent variables included concerns about seafood safety and seafood consumption. To determine Gulf seafood consumption changes, participants responded to the question "Before (or After) the Gulf Oil spill, how often did you usually eat the following seafood from the Gulf of Mexico?". The original six responses were collapsed to "never", "less than once per week", or "once per week or more". We also asked "Compared to before the Gulf oil spill, rate how your Gulf seafood consumption has changed". Responses included "decreased a lot", "decreased a little", "no change", "increased a little", and "increased a lot". For statistical purposes these were collapsed into two categories, "increased" and "decreased".

We considered participants' level of concern for the safety of eating Gulf seafood. This was assessed by a Likert scale question "Rank your concern about the safety of eating Gulf seafood" from "1" = no concern to "5" = extremely concerned. Considering participants to be concerned if they gave any response other than not concerned, responses were collapsed into a dichotomous category of "concern" or "no concern".

\section{$\underline{\text { Covariates }}$}

Participants recorded their gender, age, classification, race/ethnicity, marital status, distance from Gulf shoreline, residence status, family income, employment status, and student monthly income. We categorized classification as (1) student and (2) faculty or staff. Due to small cell numbers, race was classified as (1) white, (2) African American, or (3) other.

\section{Statistical analysis}

In this descriptive study we used SPSS 20 to conduct all analyses (International Business Machine Corporation - IBM 2013). We used the Chi square test to examine differences in categorical variables across gender, classification, and race. We considered a $P$ of less than 0.05 to be significant.

\section{Findings}

Participants were predominately female and white. Almost half were married. More than three-fourths had an income greater than $\$ 40,000$. Slightly more than half of them lived more than 60 miles from the Gulf of Mexico (Table 1). 
Table 1. Demographic Characteristics of Participants

\begin{tabular}{|l|c|c|c|c|c|c|}
\hline Characteristics & \multicolumn{2}{|c|}{ Students } & \multicolumn{2}{c|}{ Faculty/Staff } & \multicolumn{2}{c|}{ Total } \\
\hline & $\boldsymbol{N}$ & $\boldsymbol{\%}$ & $\boldsymbol{N}$ & $\boldsymbol{\%}$ & $\boldsymbol{N}$ & $\boldsymbol{\%}$ \\
\hline Female & 74 & 63.2 & 78 & 69 & 152 & 66.1 \\
\hline Male & 43 & 36.8 & 35 & 31 & 78 & 33.9 \\
\hline
\end{tabular}

\section{Race/Ethnicity}

\begin{tabular}{|l|c|c|c|c|c|c|}
\hline White & 100 & 85.5 & 98 & 80.3 & 198 & 82.8 \\
\hline Black & 4 & 3.4 & 7 & 5.7 & 11 & 4.6 \\
\hline Other & 13 & 11.1 & 17 & 13.9 & 30 & 12.6 \\
\hline Age
\end{tabular}

Age

\begin{tabular}{|l|l|l}
\hline Mean $(S D)$ & $26(8.9)$ & $45(12.4)$ \\
\hline
\end{tabular}

\section{Marital Status}

\begin{tabular}{|l|c|c|c|c|c|c|}
\hline Married & 28 & 23.9 & 85 & 75.9 & 113 & 49.3 \\
\hline Divorced & 6 & 5.1 & 8 & 7.1 & 14 & 6.1 \\
\hline Widowed & 1 & 0.9 & 0 & 0 & 1 & 0.4 \\
\hline Single & 82 & 70.1 & 19 & 17 & 101 & 44.1 \\
\hline
\end{tabular}

Income

\begin{tabular}{|c|c|c|c|c|c|c|}
\hline$<40 k$ & 33 & 32.7 & 15 & 14 & 48 & 26.1 \\
\hline$>40 k$ & 68 & 67.3 & 92 & 86 & 160 & 76.9 \\
\hline \multicolumn{7}{|c|}{ Home Town to Gulf } \\
\hline$<60$ miles & 43 & 46.7 & 44 & 40 & 87 & 43 \\
\hline$>60$ miles & 49 & 53.3 & 66 & 60 & 115 & 56.9 \\
\hline
\end{tabular}

Source: Authors' estimations.

\section{Concerns about Seafood Safety}

Respondents indicated varying levels of concern about seafood safety during and after the spill. Concern about seafood consumption varied from before the spill (17\%), during the six months after the spill $(79-82 \%)$ and a year later $(57 \%)$ (Figure 1). Before the spill when ordering seafood, only $43 \%$ of the respondents asked about the source, while $64 \%$ asked after the oil spill.

Figure 1. Overall Concern about Eating Gulf Seafood Over Time

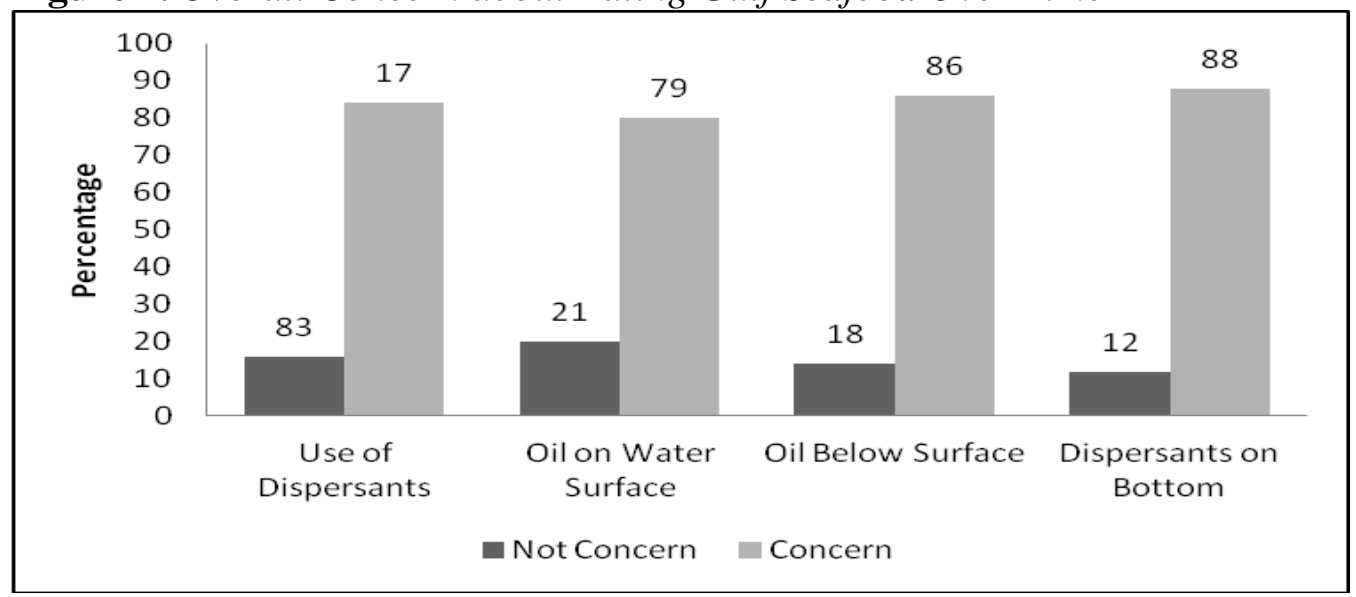

Source: Authors' estimations. 
One year after the spill, $52 \%$ of the students $(\mathrm{N}=74)$ had concern about the safety of seafood compared to $69 \%$ of the faculty/staff $(\mathrm{N}=55)$. No other timeframe was significantly different between students and faculty/staff (Table 2). In general, more females were concerned about seafood safety before and during the spill than males. However by one year later, there were no significant gender differences (Table 3 ).

Table 2. Seafood Safety Concern by Student and Faculty/Staff

\begin{tabular}{|c|c|c|c|c|c|}
\hline \multirow{2}{*}{ Time } & Student & Faculty/Staff & \multirow{2}{*}{ Chi Square } & \multirow{2}{*}{ df } & \multirow{2}{*}{$\mathbf{p}$} \\
\hline & $N(\%)$ & $N(\%)$ & & & \\
\hline Before Spill & $20(17 \%)$ & $14(17 \%)$ & 0.002 & 1 & 0.554 \\
\hline April/May & $111(78 \%)$ & $65(82 \%)$ & 0.529 & 1 & 0.293 \\
\hline June/July & $113(80 \%)$ & $68(86 \%)$ & 1.446 & 1 & 0.154 \\
\hline Aug/Sep & $110(78 \%)$ & $66(84 \%)$ & 1.157 & 1 & 0.184 \\
\hline 1 yr. later & $74(52 \%)$ & $55(69 \%)$ & 5.819 & 1 & 0.011 \\
\hline
\end{tabular}

Note: No concern $=" 1 "$ and all else $=$ "2-5".

Source: Authors' estimations.

Table 3. Seafood Safety Concern by Gender

\begin{tabular}{|c|c|c|c|c|c|}
\hline \multirow{2}{*}{ Time } & Male & Female & \multirow{2}{*}{ Chi Square } & \multirow{2}{*}{ df } & \multirow{2}{*}{ p } \\
\hline & $N(\%)$ & $N(\%)$ & & & \\
\hline Before Spill & $5(8 \%)$ & $30(22 \%)$ & 5.6 & 1 & 0.012 \\
\hline April/May & $52(68 \%)$ & $126(85 \%)$ & 7.9 & 1 & 0.005 \\
\hline June/July & $54(71 \%)$ & $130(87 \%)$ & 8.9 & 1 & 0.003 \\
\hline Aug/Sep & $52(68 \%)$ & $126(85 \%)$ & 7.9 & 1 & 0.005 \\
\hline 1 yr. later & $39(51 \%)$ & $92(61 \%)$ & 2.1 & 1 & 0.097 \\
\hline
\end{tabular}

Note: No concern = "1" and all else $=$ "2-5".

Source: Authors' estimations.

\section{Influence of Oil and Dispersants on Seafood Safety}

Out of five levels of concern from 1 (not concerned) to 5 (extremely concerned), $27 \%$ of respondents $(\mathrm{N}=62)$ were extremely concerned about the use of dispersants while $30 \%(\mathrm{~N}=61)$ had the same level of concern about the effects of dispersants that sank to the Gulf bottom. Further, $27 \%(\mathrm{~N}=61)$ were also very worried about oil below the surface of the water. Collapsing concern into dichotomous variable of concern or not concerned, $80 \%$ or more of respondents expressed concern about the effects of oil and dispersants on seafood safety (Figure 2). 
Figure 2. Concern about Effects of Oil and Dispersants on Seafood Safety

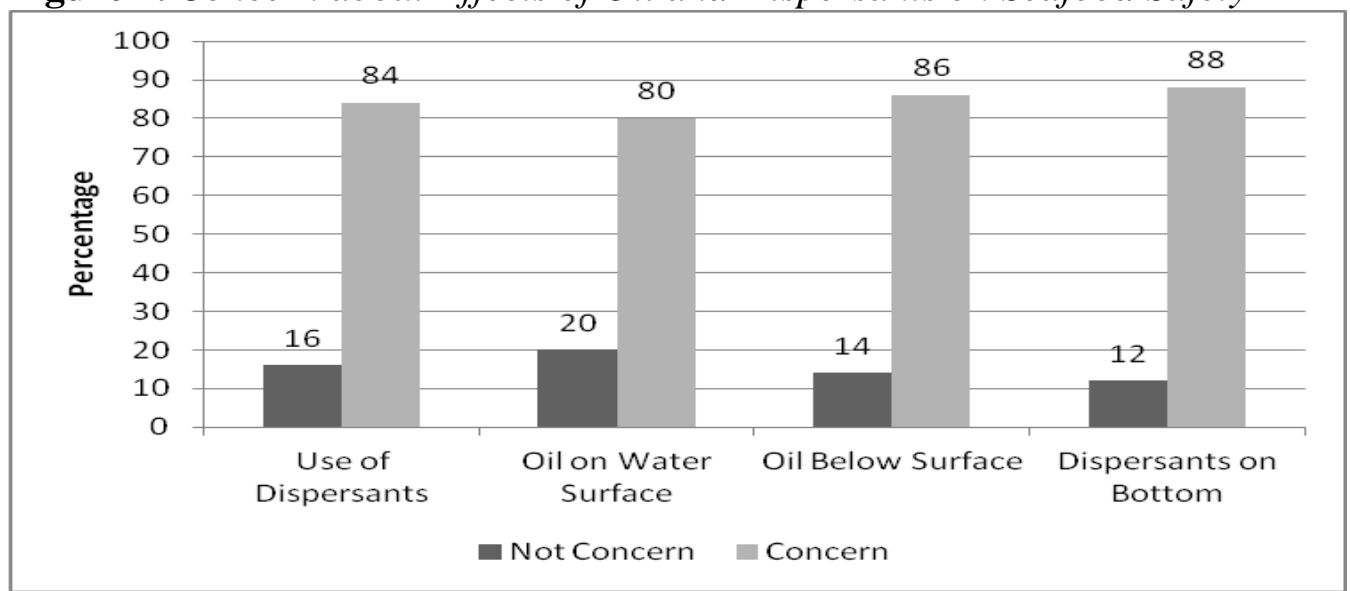

Source: Authors' estimations.

\section{Seafood Consumption Patterns}

Almost all respondents (97\%) had consumed Gulf seafood. Overall, about two-thirds $(61 \%)$ indicated no change in seafood consumption since the spill, with $35 \%$ stating a decrease and only $4 \%$ reporting an increase. There were some changes in levels of consumption of different Gulf seafood, before and after the spill; some of these decreases included reductions in intake of fish, shrimp and other seafood (Table 4). More women $(73 \%, \mathrm{~N}=57)$ indicated a decrease in seafood consumption as compared to males $(27 \%, \mathrm{~N}=21)$ after the spill, which approached statistical significance $(\mathrm{p}=0.069)$. Older participants $(35+)$ were more likely to decrease consumption $(96 \%, \mathrm{~N}=45)$ than younger participants (34 or less) $(80 \%, \mathrm{~N}=37)\left(\chi^{2}=5.225, \mathrm{df}=1, \mathrm{p}=0.023\right)$.

Table 4. Levels of Consumption for Different Gulf Seafood Products Before and After Oil Spill

\begin{tabular}{|l|c|c|c|c|c|c|}
\hline \multirow{3}{*}{ Time } & \multicolumn{2}{|c|}{$\begin{array}{c}\text { Never } \\
N(\%)\end{array}$} & \multicolumn{2}{c|}{$\begin{array}{c}\text { Once/wk } \\
\boldsymbol{N}(\%)\end{array}$} & $\begin{array}{c}\text { More than 1/wk } \\
\boldsymbol{N}(\%)\end{array}$ \\
\cline { 2 - 7 } & Before & After & Before & After & Before & After \\
\hline Fish & $187(78 \%)$ & $199(83 \%)$ & $34(14 \%)$ & $25(11 \%)$ & $13(5 \%)$ & $10(4 \%)$ \\
\hline Raw Oysters & $223(93 \%)$ & $226(95 \%)$ & $7(3 \%)$ & $6(3 \%)$ & $2(1 \%)$ & $1(0.4 \%)$ \\
\hline Cooked Oysters & $195(82 \%)$ & $194(81 \%)$ & $7(3 \%)$ & $8(3 \%)$ & $2(1 \%)$ & $0(0 \%)$ \\
\hline Shrimp & $170(71 \%)$ & $193(81 \%)$ & $45(19 \%)$ & $30(13 \%)$ & $20(8 \%)$ & $12(5 \%)$ \\
\hline Crabs & $219(92 \%)$ & $218(91 \%)$ & $6(3 \%)$ & $7(3 \%)$ & $10(4 \%)$ & $8(3 \%)$ \\
\hline Other seafood & $188(79 \%)$ & $196(82 \%)$ & $25(11 \%)$ & $21(9 \%)$ & $15(6 \%)$ & $10(4 \%)$ \\
\hline
\end{tabular}

Source: Authors' estimations.

Changes in consumption of seafood over different time periods in regard to level of concern about seafood safety were studied. Statistically significant differences were found over four time periods after the spill: April/May, June/July, August/September and one year after the spill. Over these time frames, 92\%$97.5 \%$ of those respondents who were concerned decreased their intake of seafood (Table 5). 
Table 5. Seafood Consumption by Concern and Across Time

\begin{tabular}{|l|c|c|c|c|c|c|c|c|}
\hline & \multicolumn{2}{|c|}{ April/May } & \multicolumn{2}{c|}{ June/July } & \multicolumn{2}{c|}{ August/September } & \multicolumn{2}{c|}{ One Year Later } \\
\cline { 2 - 9 } & $\begin{array}{c}\text { No } \\
\text { Concern }\end{array}$ & Concern & $\begin{array}{c}\text { No } \\
\text { Concern }\end{array}$ & Concern & $\begin{array}{c}\text { No } \\
\text { Concern }\end{array}$ & Concern & $\begin{array}{c}\text { No } \\
\text { Concern }\end{array}$ & Concern \\
\hline Decreased & $7.6 \%$ & $92.4 \%$ & $2.5 \%$ & $97.5 \%$ & $2.5 \%$ & $97.5 \%$ & $7.5 \%$ & $92.5 \%$ \\
consumption & $(6)$ & $(73)$ & $(2)$ & $(77)$ & $(2)$ & $(77)$ & $(6)$ & $(74)$ \\
\hline Increased & $36.4 \%$ & $63.6 \%$ & $45.5 \%$ & $54.5 \%$ & $45.5 \%$ & $54.5 \%$ & $72.7 \%$ & $27.3 \%$ \\
consumption & $(4)$ & $(7)$ & $(5)$ & $(6)$ & $(5)$ & $(6)$ & $(8)$ & $(3)$ \\
\hline$X^{2}=$ & $8.09(\mathrm{df}=1)$ & $24.80(\mathrm{df}=1)$ & \multicolumn{2}{c|}{$24.8(\mathrm{df}=1)$} & $31.61(\mathrm{df}=1)$ \\
& $\mathrm{p}=0.018$ & $\mathrm{P}=0.000$ & \multicolumn{2}{c|}{$\mathrm{P}=0.000$} & $\mathrm{P}=0.000$ \\
\hline
\end{tabular}

Source: Authors' estimations.

\section{Sources of Information}

Overall, participants indicated sources of information which most contributed to changes in their seafood consumption: television coverage (78\%), friends and newspapers (70\%), family and the seafood industry (67\%). Conversely, sources of information that least impacted changes in consumption patterns included government websites, government officials and politicians. As noted in Table 6, there were significant differences by gender and status. More females than males reported that TV, radio, newspapers and the seafood industry provided information that affected their seafood consumption. In addition, more faculty/staff as compared to students noted that information about seafood safety provided by TV had an impact.

Table 6. Sources of Information which Contributed to Changes in Seafood Consumption

\begin{tabular}{|c|c|c|c|c|c|c|}
\hline $\begin{array}{l}\text { Source of } \\
\text { Information }\end{array}$ & Group & No Effect & Some Effect & $\begin{array}{c}\text { Chi } \\
\text { Square }\end{array}$ & df & $\mathbf{p}$ \\
\hline \multirow[t]{4}{*}{ TV } & Faculty/Staff & $5(11 \%)$ & $40(89 \%)$ & \multirow{2}{*}{5.363} & \multirow{2}{*}{1} & \multirow{2}{*}{0.017} \\
\hline & Students & $18(30 \%)$ & $42(70 \%)$ & & & \\
\hline & Male & $13(39 \%)$ & $20(61 \%)$ & \multirow{2}{*}{7.926} & \multirow{2}{*}{1} & \multirow{2}{*}{0.006} \\
\hline & Female & $10(15 \%)$ & $59(86 \%)$ & & & \\
\hline \multirow[t]{2}{*}{ Radio } & Male & $19(58 \%)$ & $14(42 \%)$ & \multirow{2}{*}{4.146} & \multirow{2}{*}{1} & \multirow{2}{*}{0.034} \\
\hline & Female & $25(36 \%)$ & $44(64 \%)$ & & & \\
\hline \multirow[t]{2}{*}{ Newspapers } & Male & $15(46 \%)$ & $18(55 \%)$ & \multirow{2}{*}{4.295} & \multirow{2}{*}{1} & \multirow{2}{*}{0.034} \\
\hline & Female & $17(25 \%)$ & $51(75 \%)$ & & & \\
\hline \multirow{2}{*}{$\begin{array}{l}\text { Seafood } \\
\text { Industry }\end{array}$} & Male & $17(52 \%)$ & $16(49 \%)$ & \multirow{2}{*}{6.154} & \multirow{2}{*}{1} & \multirow{2}{*}{0.013} \\
\hline & Female & $18(27 \%)$ & $50(74 \%)$ & & & \\
\hline
\end{tabular}

Source: Authors' estimations.

\section{Discussion}

Among the participants, the greatest decreases in seafood consumption occurred June through September (Table 5). These months also produced the highest amounts of shrimp and crab (Audubon Nature Institute 2015). During the 
time of the oil spill there was also a great deal of press coverage about the incident. In July, the spill was capped but dispersants were still continually used. National debates were common related to the type of dispersants and their potential toxic effects (Biello 2010). Such factors may have lowered consumption levels.

Professional advice communicated to consumers can have a significant bearing on their seafood choices (Hawley et al. 2013). In our study, respondents were most influenced by television coverage, friends and newspapers, family and the seafood industry and less persuaded by information from government officials. Trust of the source of information can impact consumers' risk perceptions (Fewer et al. n.d.). Further, one's feelings about the situation, such as the need to support local fishermen/women, may have impacted perceptions of risk and in some cases, increased or maintained consumption patterns. Halfmann and Young (2010) noted the adage "a picture is worth a thousand words" may explain profound impacts on personal, social, environmental and political values. Following wide coverage of the oil spill event and the attempts to clean it up, the images and pictures on TVs and in newspapers may have created social, cultural and psychological stresses, and impacts may have resulted in varied perceptions concerning human risks at the time (Grattan et al. 2011).

\section{Gender and Age Perception Differences}

Females were more concerned, more likely to reduce seafood consumption and more likely to be influenced by all forms of media when compared with males. This is similar to findings by Anderson et al. (2011) in which women showed better food safety practices and were more aware of food safety risks compared to males. Other researchers have found that women were more likely to have higher levels of concern for food safety than men (Knight and Warland 2004). It has also been found that women were more likely to develop negative impressions about food safety (Jordan and Elnagheeb 1991). Depending on the source of information, women may trust risk communication more than males (Breakwell 2000). In our study the sources of information that had profound effects on women were television, radio, newspaper, and the seafood industry. The least trusted source of information was from US governmental organizations or those who worked in government.

Differences in age were found in terms of consumption where older participants (35+) were more likely to decrease consumption. Faculty and staff compared to students continued to have more concern about seafood safety one year after the spill. More faculty and staff than students indicated that television reporting influenced changes in their seafood consumption. In a study by Anderson et al. (2011), older participants (60+) were more aware of food safety risks as compared to younger adults $(<60 \mathrm{yrs})$. Knight and Warland (2004) also found similar results in which the level of concern for food safety increased with age. Older adults may be more aware of the perceived susceptibility and severity (Becker et al. 1974) associated with eating potentially contaminated food. This may be due to a longer period of time practicing health enhancing behaviors. 


\section{Conclusions}

Limitations of this descriptive study primarily include inability to ascribe causation. Participants self-reported answers to prescribed questions. In addition, this study was conducted one year after the DWH spill which may have resulted in recall bias. However, most individuals perceived this event as a traumatic experience and many people were thinking about the effects the spill for a long period of time. Still, this study did capture health concerns, changes in perceptions of risk, trustworthiness of media reports, and changes in consumption patterns over a one year period.

The oil spill resulted in reductions in seafood consumption which may have had negative economic impacts to the Gulf coast area. Media coverage of the event influenced perceptions of seafood safety which may have affected consumption. In our study, differences in seafood consumption and concern were influenced by both age and gender. In these circumstances, we recommend considering the use of focus groups to determine the influence of media and its effect on risk perception and consumption behaviors.

Further, longitudinal studies may help develop an understanding of the impact of oil and dispersant use on the Gulf food chain and its potential impact on human health. Accurate information should be provided for consumers to make informed decisions about food safety and consumption. Using trustworthy sources of media may assist consumers in making healthful food selections.

\section{References}

Anderson AL, Verrill LA, Sahyoun NR (2011) Food safety perceptions and practices of older adults. Public Health Reports 126: 220-227.

Audubon Nature Institute (2015) Shellfish. Retrieved from http://goo.gl/x866HK.

Becker MH, Drachman RH, Kirscht JP (1974) A new approach to explaining sick-role behavior in low income populations. American Journal of Public Health 64(3): 205-216.

Berna JL, Cassani G, Hager CD, Rehman N, Lopez I, Schowanek D, Steber J, Taeger K, Wind T (2007) Anaerobic biodegradation of surfactants - Scientific review. Tenside Surfactants Detergents 44(6): 312-347.

Biello D (2010) Is using dispersants on the BP Gulf oil spill fighting pollution with pollution? Scientific American. Retrieved from http://goo.gl/8gF4.

Breakwell GN (2000) Risk communication: Factors affecting impact. British Medical Bulletin 56(1): 110-120.

Columbia Broadcasting System - CBS News (2010, April 30). Gulf oil spill by the numbers. Retrieved from http://goo.gl/6CLWJg.

Camilli R, Reddy CM, Yorget DR, Van Mooy BA, Jakuba MV, Kinsely JC, McIntyre CP, Sylva SP, Maloney JV (2010) Tracking hydrocarbons plume transport and biodegradation at deepwater horizon. Science 330(6001): 201-204.

Crone TJ, Tolstoy M (2010) Magnitude of the 2010 Gulf of Mexico oil leak. Science 330(6004): 634. 
Deepwater Horizon Study Group (2011) Investigation of the Macondo well blowout disaster. Final report on the investigation of the Macondo well blowout. Retrieved from http://goo.gl/tSXey.

Devi S (2010) Anger and anxiety on the Gulf coast. Lancet 376(9740): 503-504.

Fewer L, de Jonge J, van Kleef E (n.d.) Medical sciences vol II., Consumer perceptions of food safety. Retrieved from http://goo.gl/9MfRK7.

Grattan LM, Mayer BM, Blackburn JK (2011) Psychological responses and resilience of people and communities impacted by the Deepwater Horizon oil spill. Transactions of the American Clinical and Climatological Association 124: 191201.

Greiner AL, Lagasse LP, Neff RAM, Love DC, Chase R, Sokol N, Smith KC (2013) Reassuring or risky: The presentation of seafood safety in the aftermath. American Journal of Public Health 103(7): 1198-1206.

Gulf of Mexico Alliance - GMA (2008) The Gulf of Mexico at a glance. Retrieved from http://goo.gl/Jm4LZu.

Halfmann D, Young M (2010) War pictures: The grotesque as a mobilizing tactic. Mobilization 15(1): 1-24.

Hawley KL, Roberto CA, Bragg MA, Liu PJ, Swartz MB, Brownell KD (2013) The science on front-of-package food labels. Public Health Nutrition 16(3): 430-439.

Hoffbauer A, Ramos H (2014) Social and political convergence on environmental events: The roles of simplicity and visuality in the BP oil spill. Canadian Sociological Association/La Soci'et'e canadienne de sociologie 51(3): 216-238.

Horowiltz A (2014) The BP oil spill and the end of Empire, Louisiana. Southern Cultures 20(3): 6-23.

International Business Machine Corporation - IBM (2013). IBM SPSS statistics for windows, version 22.0. Armonk, New York: IBM Corp.

Jordan JL, Elnagheeb AH (1991) Public perceptions of food safety. Journal of Food Distribution Research 22(3): 13-22.

Knight A, Warland R (2004) The relationship between sociodemographic and concern about food safety issues. The Journal of Consumer Affairs 38(1): 107-120.

Kilduff C, Lopez J (2011) Dispersants: The lesser of two evils or a curse worse than the disease? Ocean and Coastal Law Journal 16(2): 375-394.

Material Safety Data Sheet - MSDS (2005) COREXIT 9527A, Nalco, 1. Retrieved from http://goo.gl/SwDgBa.

McCauley LA (2010) Environments and health: Will the BP oil spill affect our health? American Journal of Nursing 110(9): 54-56.

National Commission on the BP Deepwater Horizon Oil Spill and Offshore Drilling (2011) Deep Water: The Gulf oil spill and the future of offshore drilling. Report to the President. Retrieved from http://goo.gl/gFHYtB.

National Marines Fisheries Services - NMFS (2007) Recreational fishery statistics catch snapshot query. Retrieved from http://goo.gl/o6yA90.

National Oceanic and Atmospheric Administration - NOAA (2015) Gulf of Mexico IEA: Key topics. Retrieved from http://goo.gl/VJulO4.

Plater ZJB (2010) Learning from disasters: twenty-one years after the Exxon Valdez oil spill, will reactions to the Deepwater Horizon blowout finally address the systemic flaws revealed in Alaska? Rutledge handbook of international environmental law. New York, NY: Rutledge.

Quest Offshore (2011) United States Gulf of Mexico oil and natural gas industry economic impact analysis: The economic impacts of GOM oil and natural gas development on the US economy. Retrieved from http://goo.gl/AYdNlt. 
Robertson C, Krauss C (2010, August 2) Gulf spill is the largest of its kind, scientists say. The New York Times. Retrieved from http://goo.gl/14RzdT.

Shaw SD (2010) Consensus statement: Scientists oppose the use of dispersant chemicals in the Gulf of Mexico. Marine Environmental Research Institute. Retrieved from http://goo.gl/xdfZnw.

Smith LC, Smith MK, Aschcroft PA (2011) Analysis of environmental and economic damage from British Petroleum Deep Water Horizon oil spill. Albany Law Review 74(1): 563-586.

Spotts P (2010) New BP oil spill flow estimates: 20,000 to 40,000 barrels per day. Christian Science Monitor. Retrieved from http://goo.gl/xsefxX.

Trondsen T, Scholderer J, Lund E, Eggen AE (2003) Perceived barriers to consumption of fish among Norwegian women. Appetite 41(3): 301-314.

Verbeke W, Sioen I, Pieniak Z, Van Camp J, De Henauw S (2005) Consumer perception versus scientific evidence about health benefits and safety risks from fish consumption. Journal of Public Health Nutrition 8(4): 422-429.

Walker AH, Pavia R, Bostrom A, Leschine TM, Starbird K (2015) Communication practices for oil spills: Stakeholder engagement during preparedness and response. An International Journal of Human and Ecological Risk Assessment 21(3): 667-690.

Wang P, Roberts TM (2010) Distribution of surficial and buried oil contaminants across sandy beaches along NW Florida and Alabama coasts following the Deepwater Horizon Oil Spill in 2010. Journal of Coastal Research 29(6A): 144155.

Ylitalo MG, Krahna MM, Dickhoffa WW, Stein JE, Walker CC, Lassitter CL, Garrett ES, Desfosse LL, Mitchell KM, Noble BT, Wilson S, Beck NB, Benner RA, Koufopoulos PN, Dickey RW (2012) Federal seafood response to the Deepwater Horizon oil spill. Proceedings of the National Academy of Sciences of the United States of America 109(50): 20274-20279. 
